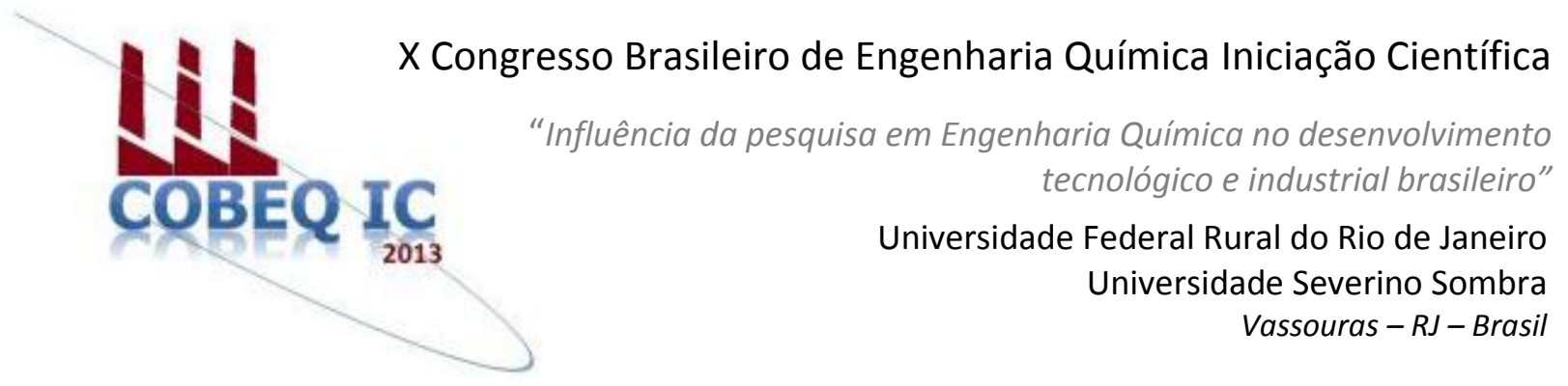

\title{
PROTEÍNA RECUPERADA DE RESÍDUOS DA INDUSTRIALIZAÇÃO DA CORVINA (Micropogonias furnieri)
}

\author{
FREIRE $^{1}$, B. P.; OLIVEIRA ${ }^{1}$, L. M.; FERREIRA ${ }^{2}$, F. A.; MARTINS ${ }^{3}$, V. G.; PRENTICE ${ }^{3}$, C. \\ ${ }^{1}$ Aluno de Graduação - LTA/EQA/FURG ${ }^{2}$ Doutorando - LTA/EQA/FURG \\ ${ }^{3}$ Professor LTA/EQA/FURG \\ Laboratório de Tecnologia de Alimentos - Escola de Química e Alimentos - \\ Universidade Federal do Rio Grande - FURG \\ Endereço - Rua Eng ${ }^{\circ}$ Alfredo Huch 475 - Rio Grande, CEP 96201-900, RS \\ email: dqmprent@ furg.br
}

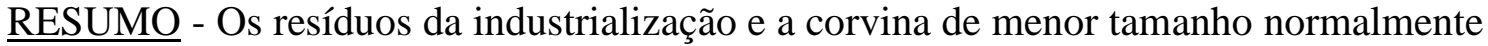
são utilizados para fabricação de farinha ou simplesmente descartados. O crescente aumento do volume de resíduos tem provocado sérios problemas para o meio ambiente, sendo que uma alternativa para minimizar este problema é o seu aproveitamento integral, através da recuperação de seus principais componentes, destacando-se a proteína. Neste trabalho recuperaram-se as proteínas oriundas de resíduos da industrialização da corvina (Micropogonias furnieri). Para obtenção das proteínas os resíduos passaram pelas etapas de separação, lavagem, centrifugação e secagem. $O$ produto final apresentou um alto teor de proteínas, 94,62 \pm 0,13\% em base seca.
\end{abstract}

Palavras chave: descartados, poluição, aproveitadas.

\section{INTRODUÇÃO}

A corvina (Micropogonias furnieri) é um peixe com distribuição conhecida desde o Golfo do México até o Golfo de San Matías, Argentina, sendo que esta espécie é comum na zona costeira do sul do Brasil. Durante seu ciclo de vida, os indivíduos juvenis migram para áreas estuarinas e os adultos alcançam a zona costeira adjacente para se reproduzir (Gonçalves e Passos, 2010).

Nos pescados o filé é a parte de maior valor econômico e seu rendimento varia de acordo com o tamanho do peixe e do domínio tecnológico das empresas de processamento. Portanto o seu rendimento pode chegar a $30 \%$ a $40 \%$ em peso do pescado, sendo o restante considerado resíduo que não possui valor comercial (restos de carne, cabeça, pele, ossos, escamas e intestinos). Assim, fontes alternativas de proteína, como os resíduos da industrialização de pescado, tornam-se importantes, pois constituem cerca de $60 \%$ a $70 \%$ da matéria-prima e, são descartados pelas indústrias causando danos ao meio ambiente (Nolsoe e Undeland, 2009).

\section{OBJETIVO}

Recuperação das proteínas oriundas de resíduos da industrialização da corvina (Micropogonias furnieri). 


\section{METODOLOGIA}

Para obtenção das proteínas foram utilizados os resíduos da industrialização da corvina (Micropogonias furnieri) obtidos em indústrias da cidade do Rio Grande, RS. A proteína foi recuperada utilizando a metodologia adaptada de Cortez-Vega et al. (2013). Os pescados foram previamente higienizados em água clorada, eviscerados, submetidos à filetagem e então, processados em separador mecânico de carne e ossos (HIGH TECH, Modelo HP250). A carne mecanicamente separada assim obtida foi lavada em três ciclos, utilizando em cada ciclo uma solução de lavagem na proporção de 4:1 (v / p), temperatura de $7^{\circ} \mathrm{C}$, durante $10 \mathrm{~min}$. Solução de $\mathrm{NaHCO}_{3}$ a $0,5 \%$ foi utilizada para a primeira e segunda lavagem e uma solução de $\mathrm{NaCl}$ a $0,3 \%$ foi utilizada para a última. $\mathrm{A}$ cada ciclo de lavagem, as amostras foram centrifugadas a 14372 x g durante $15 \mathrm{~min}$ em centrífuga de copos de alta velocidade (HANIL, Modelo Supra 22K), sendo descartado o sobrenadante que continha gordura e proteínas solúveis. O precipitado final foi seco em liofilizador (LIOTOP, Modelo L108) obtendo-se a proteína recuperada.

A avaliação do percentual de proteína na proteína recuperada foi realizada conforme metodologia oficial (AOAC, 2000).

\section{RESULTADOS E DISCUSSÃO}

Na Tabela 1, encontram-se apresentados temos o resultado do percentual de proteínas obtido na proteína recuperada dos resíduos da industrialização da corvina (Micropogonias furnieri).

\section{Tabela 1 - Percentual de proteínas obtido na proteína recuperada dos resíduos da industrialização da corvina (Micropogonias furnieri).}

\begin{tabular}{l} 
Componente \\
\hline Proteinas $(0 . s)$ \\
$94,02 \pm 0,13$ \\
$\begin{array}{l}\text { *Média de } 3 \text { repetições } \pm \text { desvio padrão; } \text { b.s }= \\
\text { base seca. }\end{array}$
\end{tabular}

Pode-se observar na Tabela 1, que a proteína recuperada apresentou alto teor de proteínas $(94,62 \%)$, resultado superior ao encontrado por Martins et al. (2009), que obtiveram $86,94 \%$ de proteínas em isolados proteicos de corvina obtidos por extração ácida e Cortez-Vega et al. (2013) que encontraram $91,00 \%$ em surimi de corvina.

\section{CONCLUSÃO}

Obteve-se um alto teor de proteínas, 94,62 \% em base seca, indicando que a metodologia utilizada foi adequada e que, a proteína recuperada dos resíduos da industrialização da corvina é uma fonte proteica que poderá ser aproveitada para a elaboração de diferentes produtos, contribuindo na diminuição da poluição ambiental.

\section{REFERÊNCIAS}

A.O.A.C. (2000), "Association of Official Analysis Chemists," 16th Edition, Washington DC.

CORTEZ-VEGA, W. R., FONSECA, G. G., FEISTHERA, V. A., SILVA. T. F. A., PRENTICE, C. (2013) "Evaluation of Frankfurters Obtained from Croaker (Micropogonias furnieri) Surimi and Mechanically Deboned Chicken Meat Surimi-Like Material," Journal of Food, v. $11, \mathrm{~N}^{\mathrm{o}} 1$, p. 27-36.

GONÇALVES, A. A., PASSOS, M. G. (2010) "Restructured Fish Product from White Croacker (Micropogonias furnieri) Mince Using Microbial Transglutaminase," Brazilian Archives of Biology and Technology, v. 53, No 4, p. 987-995.

MARTINS, V. G; COSTA, J. A. V.; PRENTICE-HERNÁNDEZ， C. (2009), Hidrolisado protéico de pescado obtido por vias química e enzimática a partir de corvina (Micropogonias furnieri). Química Nova. v. 32, № 1, p. 61-66.

NOLSOE, H.; UNDELAND, I. (2009) "The Acid and Alkaline Solubilization Process for the Isolation of Muscle Proteins: State of the Art". Food Bioprocess and Technology, v. 2, $\mathrm{N}^{\mathrm{o}}$ 1, p. 1-27. 